\title{
Response of Different Maize (Zea mays L.) Varieties to Planting Densities
}

\author{
Mege Duchok*, Tara Bhuyan, V. S. Devadas, Sheelawati Monlai and Avinash Sharma
}

Department of Agronomy, Arunachal University of Studies, Namsai, (Arunachal Pradesh), India

*Corresponding author

An experiment was conducted at the Agriculture Research farm of the Arunachal Universities of Studies, Namsai, Arunachal Pradesh during rabi season 2018-19 to study the response of different maize varieties to the planting densities. The experiment was

Keywords

Maize,

Planting densities, rabi season, Bond NMH 007

Article Info

\section{Accepted:}

12 January 2021

Available Online:

10 February 2021 conducted with twelve treatment combinations comprising of four planting densities viz., $\mathrm{S} 1(70 \mathrm{~cm} \times 20 \mathrm{~cm}), \mathrm{S} 2(60 \mathrm{~cm} \times 20 \mathrm{~cm}), \mathrm{S} 3(50 \mathrm{~cm} \times 20 \mathrm{~cm}), \mathrm{S} 4(40 \mathrm{~cm} \times 20 \mathrm{~cm})$ and three varieties V1 (Bond NMH 007), V2 (HQPM-1), V3 (Local) in a split plot design with three replications. The results revealed that the variety Bond NMH 007 was superior to other varieties. Although maximum plant height $(220.35 \mathrm{~cm})$ was observed in the Local variety whereas the other growth parameters were found to be the highest in variety Bond NMH 007 such as number of leaves (10.83), number of cobs $(2.00)$, ear diameter $(16.70 \mathrm{~cm})$, cob length $(21.53 \mathrm{~cm}), 50 \%$ tasselling $(85.79)$, fresh weight $(181.33 \mathrm{~g})$, dry weight $(141.78 \mathrm{~g})$, number of seed per cob (315.96), grain yield per plant (126.37 g) and grain yield per plot $(2.24 \mathrm{~kg})$. Among different planting densities $S 1(70 \mathrm{~cm} \times 20 \mathrm{~cm})$ recorded highest value for plant height at 120 days after planting $(191.47 \mathrm{~cm})$, diameter of ear per plant $(15.92 \mathrm{~cm})$, cob length per plant $(20.58 \mathrm{~cm})$, days to $50 \%$ tasselling $(81.22$ days $)$, number of seed per cobg (286.83). Fresh weight per cob (175.75g), dry weight $(137.22 \mathrm{~g})$ and highest grain yield per plant $(119 \mathrm{~g})$. The results also showed that planting density $S 1(70 \mathrm{~cm} \times 20 \mathrm{~cm})$ with V1(Bond NMH 007) variety obtained highest value for most of the parameters.

\section{Introduction}

Maize (Zea mays L.) belonging to Poaceae (Gramineae) is one of the most important cereal crops in the global agricultural economy both as food as well as for man and feed for animals and is also known as 'queen of cereals'. Maize being " $\mathrm{C} 4$ and day-neutral plant," has a very high yield potential. It is one of the most versatile crops with wider adaptability in varied agro-ecologies. The highest maize producing countries are United State at number one position accounting for about 38\%, followed by china $23 \%$ respectively. Whereas, India contributes around $2 \%$. According to farm ministry data India produced only 15.5 million tonnes maize in year 2015-16 kharif season, falling from 17.01 million tonnes a years ago. Similarly, there was fall in production by nearly $23 \%$ on the same year to 5.53 million tonnes due to soil moisture stress. However, 
in year 2016-17 production of maize recorded to be increased by 23000 thousand metric tonnes. Maize is one of the most popular cereal crop cultivated next to rice, millet, wheat etc. in Arunachal Pradesh. According to latest crop production Statistics of Department of Agriculture, Arunachal Pradesh 2016-17, maize is grown under the area of 40703 ha with an output of 59907 metric tonnes during Kharif season. During Rabi season it is grown under the area of 9597 ha with the annual production of 15543 metric tonnes. Major maize producing districts of Arunachal Pradesh are Tawang, East Kameng, Upper Subansiri, East Siang and Papumpare. As in the case of any other crops production and productivity of maize is also influenced by the genetic makeup or varietal character. Varieties suited to specific agro climatic condition are to be identified and popularized. Maize is a non-tillering crop, and each plant counts for the yield. Unlike tillering plants such as rice or wheat, maize cannot compensate for lost space therefore, it is very important that plant density is maintained in maize. Pepó and Sárvári (2013), reported that maize is a plant with individual productivity and therefore plant density determines yield significantly. Plant density is a production factor that affects yield to the greatest extent. Overcrowding may reduce yields lead to poor quality of fruits. Spacing also plays an important role in disease management by reducing the risk of diseases which are contagious and also improves the immune system of the crop.

\section{Materials and Methods}

The field experiment was carried out during rabi season, 2018-2019 at the Agriculture Research Farm of Arunachal University of Studies, Namsai. The effect of three different variety (V1=Bond NMH007, V2=HQPM-1 and V3=Local) with four planting densities $(\mathrm{S} 1=70 \mathrm{~cm} \times 20 \mathrm{~cm}, \mathrm{~S} 2=60 \mathrm{~cm} \times 20 \mathrm{~cm}$,
$\mathrm{S} 3=50 \mathrm{~cm} \times 20 \mathrm{~cm}$ and $\mathrm{S} 4=40 \mathrm{~cm} \times 20 \mathrm{~cm}$ ) on growth and yield characters of maize was evaluated in split plot technique with twelve treatment combination with three replication each. The maize varieties where planted during the second week of December. Five plants were selected randomly from the net plot in each treatment and replication and tagged for the purpose of recording different observation. The various observations on growth and yield were recorded and analysed statistically.

\section{Results and Discussion}

The results obtained from the present investigation as well as relevant discussion have been summarized under the following headings:

\section{Effect of variety on crop characters and yield contributing characters of maize}

The plant height $(\mathrm{cm})$, number of leaves per plant, days to $50 \%$ tasselling, number of cobs per plant, ear diameter $(\mathrm{cm})$, cob length $(\mathrm{cm})$, fresh weight and dry weight of cobs per plant $(\mathrm{g})$, number of seeds per cob and grain yield per plant (g) were significantly influenced by various varieties (Table 1a \& Table $1 b)$. In the present study, variety V3 (local) recorded highest plant height of $220.35 \mathrm{~cm}$ and lowest $(174.07 \mathrm{~cm})$ by V1 (Bond NMH007 (Table 1a). Highest number of leaves (10.83) was recorded by V1 (Bond NMH007) and lowest number of leaves (8.55) by V1 (Local) (Table 1a). The maximum days (85.79days) was recorded by V1 (Bond NMH 007) whereas V3 (Local) recorded minimum days (67.58 days) to $50 \%$ tasselling (Table 1a). The number of cobs per plant was found to be superior in variety V1 (Bond NMH 007) of 2.00 and the other two varieties V2 (HQPM-1) and V3 (Local) where at par i.e. 1.65 and 1.61 respectively (Table 1a). 
Table.1a Effect of variety plant height, number of leaves per plant, days to $50 \%$ tasselling, number of cobs per plant, ear diameter and cob length

\begin{tabular}{|c|c|c|c|c|c|c|}
\hline Variety & $\begin{array}{l}\text { P I a n } \\
\text { t height } \\
(\mathrm{cm})\end{array}$ & $\begin{array}{l}\text { Number } \\
\text { of } 1 \text { e a } \mathrm{v} \\
\text { e } \mathrm{s} \\
\text { plant-1 }\end{array}$ & $\begin{array}{l}\text { Days to } \\
50 \% \\
\text { tasselling }\end{array}$ & $\begin{array}{l}\text { Numb } \\
\text { er of } \\
\text { cobs } \\
\text { palnt-1 }\end{array}$ & $\begin{array}{ll}\mathbf{E} & \mathbf{a} \\
(\mathrm{cm}) & \mathbf{r}\end{array}$ & $\begin{array}{l}\text { C o b } \\
(\mathrm{cm})\end{array}$ \\
\hline $\begin{array}{l}\text { V1- Bond } \\
\text { NMH007 }\end{array}$ & 173.66 & 10.83 & 85.79 & 2.00 & 16.70 & 21.53 \\
\hline $\begin{array}{l}\text { V } 2 \\
\text { HQPM-1 }\end{array}$ & 172.21 & 10.31 & 83.95 & 1.65 & 15.45 & 18.20 \\
\hline V3-Local & 220.35 & 8.55 & 67.58 & 1.61 & 13.03 & 17.43 \\
\hline $\operatorname{CD}(5 \%)$ & 4.05 & 1.79 & 0.81 & 0.26 & 0.65 & 0.73 \\
\hline S.Em ( $( \pm)$ & 1.00 & 0.44 & 0.20 & 0.06 & 0.16 & 0.18 \\
\hline
\end{tabular}

Table.1b Effect of variety on fresh weight, dry weight, number of seeds per cob and grain yield per plant

\begin{tabular}{|l|l|l|l|l|}
\hline Variety & $\begin{array}{l}\text { Fresh weight } \\
(\mathbf{g})\end{array}$ & Dry weight $(\mathbf{g})$ & $\begin{array}{l}\text { Number of seeds } \\
\text { plant }-\mathbf{1}\end{array}$ & $\begin{array}{l}\text { Graing yield plant-1 } \\
(\mathbf{g})\end{array}$ \\
\hline $\begin{array}{l}\text { V1- Bond } \\
\text { NMH007 }\end{array}$ & 181.33 & 141.78 & 315.96 & $\mathbf{1 2 6 . 3 7}$ \\
\hline $\begin{array}{l}\text { V 2 } \\
\text { HQPM-1 }\end{array}$ & 159.46 & 122.90 & 248.70 & $\mathbf{1 1 1 . 3 3}$ \\
\hline V3-Local & 140.11 & 103.86 & 216.33 & $\mathbf{8 2 . 7 2}$ \\
\hline CD(5\%) & 3.06 & 0.67 & 1.99 & $\mathbf{7 . 1 0}$ \\
\hline S.Em $(\mathbf{\pm})$ & $\mathbf{0 . 8 3}$ & $\mathbf{0 . 1 6}$ & $\mathbf{0 . 4 9}$ & $\mathbf{1 . 7 6}$ \\
\hline
\end{tabular}

Table.2a Effect of planting density on plant height, number of leaves per plant, days to $50 \%$ tasselling, number of cobs per plant, ear diameter and cob length

\begin{tabular}{|c|c|c|c|c|c|c|}
\hline Variety & $\begin{array}{l}\text { P l a n t } \\
\text { height } \\
(\mathrm{cm})\end{array}$ & $\begin{array}{l}\text { Number of } \\
\text { l e a e s } \\
\text { plant }^{-1}\end{array}$ & $\begin{array}{l}\text { Days to } 50 \% \\
\text { tasselling }\end{array}$ & $\begin{array}{l}\text { Number } \\
\text { of cobs } \\
\text { palnt }^{-1}\end{array}$ & $\begin{array}{l}\mathbf{E} \quad \mathbf{r} \\
\text { diameter } \\
(\mathrm{cm})\end{array}$ & $\begin{array}{l}\text { Co b } \\
\text { l e ngth } \\
(\mathrm{cm})\end{array}$ \\
\hline $\begin{array}{l}\text { S1- } \\
70 \mathrm{~cm} \times 20 \mathrm{~cm}\end{array}$ & 191.47 & 9.77 & 79.54 & 1.84 & 15.92 & 20.58 \\
\hline $\begin{array}{l}S 2- \\
6 \mathrm{~cm} \times 20 \mathrm{~cm}\end{array}$ & 186.35 & 10.13 & 81.22 & 1.77 & 15.38 & 19.12 \\
\hline $\begin{array}{l}\mathrm{S3-} \\
50 \mathrm{~cm} \times 20 \mathrm{~cm}\end{array}$ & 189.07 & 10.13 & 78.25 & 1.73 & 15.05 & 18.18 \\
\hline $\begin{array}{l}\text { S4- } \\
40 \mathrm{~cm} \times 20 \mathrm{~cm}\end{array}$ & 188.07 & 9.66 & 77.42 & 1.66 & 13.90 & 18.33 \\
\hline $\operatorname{CD}(5 \%)$ & 3.24 & NS & 1.45 & NS & 0.72 & 0.79 \\
\hline S.Em ( $( \pm)$ & 1.08 & $0 . .23$ & 0.48 & 0.10 & 0.24 & 0.26 \\
\hline
\end{tabular}


Table.2b Effect of planting density on fresh weight, dry weight, number of seeds per cob and grain yield per plant

\begin{tabular}{|l|l|l|l|l|}
\hline Variety & Fresh weight (g) & $\begin{array}{l}\text { Dry weight } \\
(\mathrm{g})\end{array}$ & $\begin{array}{l}\text { N u m b e r } \\
\text { f } \\
\text { seends nlant-1 }\end{array}$ & $\begin{array}{l}\text { Graing yie l } \\
\text { d } \\
\text { nlant-1 (o) }\end{array}$ \\
\hline $\begin{array}{l}\text { S1- } \\
\mathbf{7 0 c m} \times \mathbf{2 0 c m}\end{array}$ & 175.75 & 137.22 & 286.83 & $\mathbf{1 1 4 . 0 0}$ \\
\hline $\begin{array}{l}\text { S2- } \\
\mathbf{6 c m} \times \mathbf{2 0 c m}\end{array}$ & 157.00 & 122.25 & 255.17 & $\mathbf{1 0 7 . 9 4}$ \\
\hline $\begin{array}{l}\text { S3- } \\
\mathbf{5 0 c m} \times \mathbf{2 0 c m}\end{array}$ & 158.27 & 117.42 & 253.22 & $\mathbf{1 0 3 . 2 1}$ \\
\hline $\begin{array}{l}\text { S4- } \\
\mathbf{4 0 c m} \times \mathbf{2 0 c m}\end{array}$ & 150.47 & 114.49 & 246.11 & $\mathbf{1 0 2 . 0 8}$ \\
\hline $\mathbf{C D}(\mathbf{5 \%})$ & 1.33 & 1.26 & 2.58 & $\mathbf{4 . 2 1}$ \\
\hline $\mathbf{S . E m}(\mathbf{(})$ & $\mathbf{0 . 4 4}$ & $\mathbf{0 . 4 2}$ & $\mathbf{0 . 8 6}$ & $\mathbf{1 . 4 0}$ \\
\hline
\end{tabular}

Table.3a Interaction effect of planting density and variety on plant height, number of leaves per plant, days to $50 \%$ tasselling, number of cobs per plant, ear diameter and cob length

\begin{tabular}{|l|l|l|l|l|l|l|}
\hline Variety & $\begin{array}{l}\text { Plant } \\
\text { height } \\
\text { (cm) }\end{array}$ & $\begin{array}{l}\text { Number } \\
\text { of leaves } \\
\text { plant-1 }\end{array}$ & $\begin{array}{l}\text { Days to } \\
\mathbf{5 0 \%} \\
\text { tasselling }\end{array}$ & $\begin{array}{l}\text { Number } \\
\text { of cobs } \\
\text { palnt-1 }\end{array}$ & $\begin{array}{l}\text { Ear } \\
\text { diameter } \\
\text { (cm) }\end{array}$ & $\begin{array}{l}\text { Cob } \\
\text { length } \\
\text { (cm) }\end{array}$ \\
\hline T1-V1S1 & 171.82 & 11.06 & 86.85 & 2.33 & 17.58 & $\mathbf{2 3 . 9 3}$ \\
\hline T2-V1S2 & 174.00 & 11.06 & 85.30 & 1.93 & 16.64 & $\mathbf{2 1 . 1 6}$ \\
\hline T3-V1S3 & 175.00 & 10.53 & 85.77 & 1.93 & 16.23 & $\mathbf{2 0 . 4 2}$ \\
\hline T4-V1S4 & 173.83 & 10.67 & 85.26 & 1.80 & 16.23 & $\mathbf{2 0 . 6 0}$ \\
\hline T5-V2S1 & 181.20 & 9.53 & 86.12 & 1.66 & 15.83 & $\mathbf{1 9 . 7 5}$ \\
\hline T6-V2S2 & 167.06 & 10.80 & 84.70 & 1.46 & 15.76 & $\mathbf{1 8 . 8 1}$ \\
\hline T7-V2S3 & 177.53 & 10.46 & 84.00 & 1.66 & 15.90 & $\mathbf{1 7 . 1 3}$ \\
\hline T8-V2S4 & 163.06 & 10.46 & 81.00 & 1.80 & 14.33 & $\mathbf{1 7 . 1 3}$ \\
\hline T9-V3S1 & 227.40 & 8.73 & 65.66 & 1.53 & 14.34 & $\mathbf{1 8 . 0 6}$ \\
\hline T10-V3S2 & 218.00 & 8.53 & 73.66 & 1.93 & 13.75 & $\mathbf{1 7 . 4 0}$ \\
\hline T11-V3S3 & 214.70 & 8.53 & 65.00 & 1.60 & 14.33 & $\mathbf{1 7 . 0 0}$ \\
\hline T12-V3S4 & 221.33 & 7.86 & 66.00 & 1.40 & 11.15 & $\mathbf{1 7 . 2 6}$ \\
\hline CD(5\%) & 6.15 & NS & 2.32 & NS & NS & NS \\
\hline S.Em $(\mathbf{\pm})$ & $\mathbf{2 . 0 0}$ & $\mathbf{0 . 8 9}$ & $\mathbf{0 . 7 5}$ & $\mathbf{0 . 1 3}$ & $\mathbf{0 . 3 2}$ & $\mathbf{0 . 3 6}$ \\
\hline & & & & & & \\
\hline
\end{tabular}


Table.3b Interaction effect of planting density and variety on fresh weight, dry weight, number of seeds per cob and grain yield per plant

\begin{tabular}{|l|c|c|c|c|}
\hline Variety & Fresh weight $(\mathbf{g})$ & $\begin{array}{c}\text { Dry weight } \\
(\mathbf{g})\end{array}$ & $\begin{array}{c}\text { Number of } \\
\text { seeds plant-1 }\end{array}$ & $\begin{array}{c}\text { Grain } \\
\text { plant-1 (g) }\end{array}$ \\
\hline T1-V1S1 & 216.00 & 173.30 & 355.00 & 128.33 \\
\hline T2-V1S2 & 171.00 & 132.48 & 301.86 & 128.82 \\
\hline T3-V1S3 & 178.00 & 133.00 & 316.00 & 125.66 \\
\hline T4-V1S4 & 160.33 & 128.33 & 291.00 & 122.66 \\
\hline T5-V2S1 & 155.67 & 117.18 & 285.83 & 120.66 \\
\hline T6-V2S2 & 157.00 & 118.00 & 246.00 & 112.3 \\
\hline T7-V2S3 & 164.83 & 127.28 & 230.00 & 106.66 \\
\hline T8-V2S4 & 160.33 & 129.15 & 233.00 & 105.66 \\
\hline T9-V3S1 & 154.70 & 121.18 & 219.66 & 93.00 \\
\hline T10-V3S2 & 143.00 & 116.28 & 217.66 & 82.66 \\
\hline T11-V3S3 & 130.00 & 92.00 & 213.66 & 77.31 \\
\hline T12-V3S4 & 130.75 & 86.00 & 214.33 & 77.93 \\
\hline CD(5\%) & 2.30 & 2.23 & 4.68 & NS \\
\hline S.Em $( \pm)$ & 1.66 & 0.33 & 0.98 & 3.52 \\
\hline
\end{tabular}

Among variety highest ear diameter (16.70 $\mathrm{cm}$ ) was recorded by V1(Bond NMH007) lowest ear diameter was recorded by V3 (Local) of $13.03 \mathrm{~cm}$ (Table 1b). The highest cob length $(21.53 \mathrm{~cm})$ was found in V1 (Bond NMH007) and lowest cob length $(17.43 \mathrm{~cm})$ was obtained in V3 (Local). The results are in conformity with Gozubenii et al., (2001) in maize who reported that variation in ear characteristics of maize depends upon the genotype and environmental conditions. The result showed that V1 (Bond NMH007) recorded highest fresh weight of $181.33 \mathrm{~g}$ and dry weight of $141.78 \mathrm{~g}$ and the lowest fresh weight (140.11g) and dry weight (103.86g) was recorded by V3 (Local) (Table 1b). A similar report was also obtained by Zamir et al., (2011). The results showed that V1 (Bond NMH007) recorded maximum number of seeds per cob of 315.96 and the lowest was recorded by V3 (Local) of 216.33 (Table 1b). The highest grain yield (126.37g) was recorded by V1 (Bond NMH007) and lowest grain yield $(82.72 \mathrm{~g})$ was recorded by $\mathrm{V} 3$
(Local) (Table 1b). This may be due to specific varietal and environmental factors such as climate, soil, water, topography etc.

Effect of planting density on crop characters and yield contributing characters of maize

The planting density had a significant effect on plant height, ear diameter, cob length, days to $50 \%$ tasselling, fresh weight, dry weight, number of seeds per cob and yield per plant (Table 2a \& 2b). The plant height was highest at wider spacing of $\mathrm{S} 1(70 \mathrm{~cm} \times 20 \mathrm{~cm})$ of $191.47 \mathrm{~cm}$ and lowest plant height (186.35) was obtained in S4 (40cm x 20cm) (Table 2a). The planting density $\mathrm{S} 1(70 \mathrm{~cm} \times 20 \mathrm{~cm})$ recorded highest ear diameter $(15.92 \mathrm{~cm})$ and the lowest was recorded by $\mathrm{S} 4(40 \mathrm{~cm} \times 20 \mathrm{~cm})$ of $13.90 \mathrm{~cm}$, whereas S2 and S3 were at par (Table 2a). The cob length was highest in S1 $(70 \mathrm{~cm} \times 20 \mathrm{~cm})$ of $20.58 \mathrm{~cm}$ and the lowest was recorded by $\mathrm{S} 3(50 \mathrm{~cm} \times 20 \mathrm{~cm})$ of $18.18 \mathrm{~cm}$. The data revealed that cob length decreased 
with increasing planting density (Table 2a). These results indicate that there is a positive relationship between plant spacing and cob length of maize, which may be probably due to variable plant competition. Similar results were founr by Zamir et al., (2011) and Karim et al., (1983) in maize. The maximum days taken to $50 \%$ tasselling was recorded in $\mathrm{S} 2$ $(60 \mathrm{~cm} \times 20 \mathrm{~cm})$ of 81.22 days and minimum was recorded by $\mathrm{S} 4 \quad(40 \mathrm{~cm} \times 20 \mathrm{~cm})$ of 77.42 days, whereas $\mathrm{S} 1(70 \mathrm{~cm} \times 20 \mathrm{~cm})$ of 79.54 days and $\mathrm{S} 3(50 \mathrm{~cm} \times 20 \mathrm{~cm})$ of 78.25 days are at par (Table 2a). The highest fresh weight (175.75g) and dry weight (137.22g) was recorded by $\mathrm{S} 1(70 \mathrm{~cm} \times 20 \mathrm{~cm})$ and lowest fresh weight $(150.47 \mathrm{~g})$ and dry weight $(114.49 \mathrm{~g})$ was recorded by $\mathrm{S} 4(40 \mathrm{~cm} \times 20 \mathrm{~cm})$ (Table 2a). The highest number of seeds per cob was recorded in $\mathrm{S} 1 \quad(70 \mathrm{~cm} \times 20 \mathrm{~cm})$ of 286.83 and lowest was recorded by $\mathrm{S} 4$ $(40 \mathrm{~cm} \times 20 \mathrm{~cm})$ of 246.11 (Table 2b). The highest grain yield per plant was recorded in $\mathrm{S} 1(70 \mathrm{~cm} \times 20 \mathrm{~cm})$ of $114.00 \mathrm{~g}$ and the lowest was recorded by $\mathrm{S} 4(40 \mathrm{~cm} \times 20 \mathrm{~cm})$ of $102.08 \mathrm{~g}$ (Table 2b). Hasan et al., (2018) recorded longest plant, highest cob, maximum diameter of cob, highest number of kernel per cob, the highest 1000 grain weight, maximum grain yield and maximum stover yield in spacing of $75 \mathrm{~cm} \times 25 \mathrm{~cm}$. Sabo et al., (2016) reported that wider intra-row spacing in maize of $25 \mathrm{~cm}$ recorded highest plant height, number of leaves, leaf area, number of cob per plot, cob length, 100 seed weight and grain yield.

\section{Interaction effect of planting density and varieties of growth and yield characters of maize}

The interaction effect of planting density and variety was found to be significant for plant height, days to $50 \%$ tasselling, fresh weight, dry weight and number of seeds per cob (Table 3a \&3b). The tallest plant height $(227.40 \mathrm{~cm})$ was obtained from interaction effect of Local variety with $\mathrm{S} 1(70 \mathrm{~cm} \times$
$20 \mathrm{~cm}$ ) and smallest plant (163.06) was recorded by variety HQPM-1 with $S 1(70 \mathrm{~cm}$ $\mathrm{x} 20 \mathrm{~cm}$ ), (Table:3a). The maximum days (86.85 days) taken to $50 \%$ tasselling was recorded by the T3 (V1S2) whereas minimum days (65.00 days) was recorded in T11(V3S3), (Table:3a). The highest fresh weight was recorded by the T1 (V1S1) is $216.00 \mathrm{~g}$ whereas lowest was recorded in T12(V3S4) is $130.75 \mathrm{~g}$. The maximum dry weight was recorded by the T1 (V1S1) is $173.30 \mathrm{~g}$ whereas T12 (V1S1) recorded the lowest dry weight of $86.00 \mathrm{~g}$, (Table:3b).. The highest number of seed per cob was recorded by the T1 (V1S1) is 355.00 whereas T11 (V3S3) recorded lowest number of seeds per cob is 213.66 which is at par with T12 (V3S4) is 214.33, (Table:3b). Wider spacing produce higher seed, result is supported by Gulluoglu et al., (2017).

The results thus obtained from this investigation concluded that planting density of maize is an important factor to get a optimum growth and yield. From the finding of present experiment it can be concluded that variety V1 (Bond NMH 007) is more suitable than the other two varieties. Spacing S1 $(70 \mathrm{~cm} \times 20 \mathrm{~cm})$ has been found to be the ideal spacing for Namsai region. Wider spacing has influence on growth parameters this may be due to efficient utilization of light, space, moisture and aeration for growth and development. Variety Bond NMH 007 found to be the most superior and its performance was consistently superior to that of the other varieties followed by HQPM-1.

\section{References}

Anonymous, (2017). Published by Agricultural Development Officer, Pasighat, under the Department of Agriculture, Govt. of Arunachal Pradesh, India

Casini, P. (2012). Maize production as 
affected by sowing date, plant density and row spacing in the Bolivian Amazon. Journal of Agriculture and Environment for International Development. 106(2): 75-84.

Gozubenli, H., Ulger, A.C. and Sener, O. (2001). The effect of different nitrogen doses on grain yield and yield-related characters of some maize genotypes grown as second crop. J. Agric. Fac., 16: $39-48$

Gulluoglu, L., Bakal, H., Sabagh, A.E. and Arioglu. H. (2017). Soybean managing for maximize production: plant population density effects on seed yield and some agronomical traits in main cropped soybean production. Journal of Experimental Biology and Agricultural Sciences. 5(1): 31-37.

Hasan, M.R., Rahman, M.R., Hasan, A.K., Paul, S.K. and Alam. A.H.M.J. (2018). Effect of Variety and Spacing on the Yield Performance of maize (Zea mays L.) in Old Brahmaputra Floodplain Area of Bangladesh. Archives of Agriculture and Environmental Science. 3(3): 270274.

Karim, M., Baksh, A. and Shah, P. (1983), Effect of plant population on yield and yield components of synthetic 66 maize. Journal of Agriculture Research. 21(1):57-69

Pepó P., Sárvári M. (2013). Agrotechnikai változások. Magyar Mezőgazdaság. 2431.

Sabo, M.V., Wailare, M.A., Aliyu, M. and Sanusi, J. (2016). effect of variety and spacing on growth and yield of Maize (Zea mays L.) in Bauchi state, Nigeria, International Journal of plant and Soil Italic. 9(6): 1-6.

Zamir, M.S.I, Ahmad, A.H., Javeed, H.M.R. and Latif, T. (2011). Growth and yield behaviour of two maize hybrids (Zea mays. L) towards different plant spacing. Cercetari Agronomice in Moldova.44 (2): 33-40.

\section{How to cite this article:}

Mege Duchok, Tara Bhuyan, V. S. Devadas, Sheelawati Monlai and Avinash Sharma. 2021. Response of Different Maize (Zea mays L.) Varieties to Planting Densities. Int.J.Curr.Microbiol.App.Sci. 10(02): 1278-1284. doi: https://doi.org/10.20546/ijcmas.2021.1002.151 